\title{
Biochemical and histological changes in osteoarthritic synovial membrane
}

\author{
O GEDIKOGLU, ${ }^{2}$ M T BAYLISS, ${ }^{1}$ S Y ALI, ${ }^{1}$ AND I TUNCER
}

From the 'Experimental Pathology Unit, Institute of Orthopaedics (University of London), Royal National Orthopaedic Hospital, Stanmore, Middlesex; and the ${ }^{2}$ University of Hacettepe, Ankara, Turkey

SUMMARY In order to investigate the relationship between the synovial inflammatory response and lysosomal enzyme activity in osteoarthritis, synovial specimens obtained from 19 osteoarthritic patients and control specimens from 10 normal joints were analysed for cathepsin $\mathrm{D}$ and acid phosphatase enzyme levels. In estimating enzyme activities methods previously developed for quantitative enzyme determination in cartilage were modified and applied to synovial tissues for the first time. In addition, samples of osteoarthritic synovium were histologically graded according to their degree of inflammation. It was found that in osteoarthritic synovium cathepsin $\mathrm{D}$ and acid phosphatase, which is a general marker for lysosomal enzyme activity, were significantly increased compared with normal control synovium. No significant relationship was found between the degree of synovial tissue inflammation and lysosomal enzyme activity.

Key words: lysosomal enzymes, cathepsins, cartilage breakdown, inflammation.

In osteoarthritis there is a progressive loss of ground substance, which leads to the destruction of articular cartilage and eventually to joint failure. It has been established that in osteoarthritic cartilage the activity of lysosomal enzymes such as cathepsin D and acid phosphatase is increased, and it has been suggested that these enzymes are partly responsible for cartilage breakdown. ${ }^{12}$ Since the cartilage destruction starts at the superficial layers ${ }^{3}$ and synovial inflammation of varying degrees is present from the earliest stages of experimental osteoarthritis ${ }^{4}$ it has been suggested that synovial tissue may have a role in cartilage destruction. ${ }^{5}$ Increased lysosomal enzyme activity has also been shown in synovial tissue, ${ }^{67}$ and Glynn ${ }^{8}$ has postulated that the main cause of cartilage destruction may be due to the lack of enzyme inhibitors. However, there are various conflicting reports in the literature..$^{379} 10 \mathrm{In}$ this study we have attempted to clarify the role of synovium in cartilage destruction, by determining the relationship between the degree of inflammation in synovium and the lysosomal enzyme activities by quantitative methods of estimation. 21112

Accepted for publication 20 August 1985.

Correspondence to Dr S Y Ali. Experimental Pathology Unit. Royal National Orthopaedic Hospital, Brockley Hill. Stanmore. Middlesex HA7 4LP.

\section{Materials and methods}

Synovial tissues obtained from 19 patients undergoing total hip replacement for osteoarthritis were used in this study. A total of 10 cases of femoral neck fractures treated with prosthetic replacement and limb amputations for various reasons were used to obtain control 'normal' synovial tissue. Eight of the control samples were from the hip and two from the knee. In each case part of the synovial membrane was fixed in $10 \%$ formaldehyde, sectioned, and stained with haematoxylin-eosin for histological grading. The remaining fresh tissue was prepared for enzyme studies according to the methods previously described by us. ${ }^{11-13}$

Cathepsin D activity was determined by a quantitative method described by Ali and Bayliss ${ }^{2}$ which is based on the hydrolysis of haemoglobin denatured with urea. Enzyme activity was expressed as $\mathrm{mg}$ tyrosine/g synovial tissue. Acid phosphatase activity was determined under similar conditions by measuring the release of inorganic phosphate from $\mathrm{Na} \beta$ glycerophosphate and expressed as $\mathrm{mg}$ phosphate/g wet weight of synovial tissue. The enzyme levels determined for osteoarthritic synovium and control synovium were compared with each other by the Student's $t$ test.

Histological criteria described by Salvati et al. ${ }^{7}$ 
Table 1 Groups according to the degree of inflammation

\begin{tabular}{lll}
\hline Group & Degree of inflammation & Score \\
\hline I & Minimal & $0-5$ \\
II & Moderate & $6-10$ \\
III & Advanced & 11 and over \\
\hline
\end{tabular}

The statistical relationship between these groups and the degree of lysosomal enzyme activity was determined by the Mann-Whitney $U$ test.

were used for evaluation of the inflammatory response of synovial tissue in osteoarthritis: (a) focal chronic inflammation (lymphoid follicles) $-1+, 2+$, $3+=1-2,3-6$, and 7 or more lymphoid follicles/low power field respectively; $(b)$ diffuse chronic inflammation (lymphocytes and plasma cells)-1+, $2+, 3+=1-9,10-49$, and 50 or more cells/high power field $(\times 500)$ respectively; $(c)$ acute inflammation (polymorphonuclear leucocytes) $-1+, 2+$, $3+=1-9,10-49$, and 50 or more cells/high power field $(\times 500)$ respectively; $(d)$ proliferative hyperplasia of synoviocytes $-1+, 2+, 3+=2-3,3-5$, and 6 or more synoviocytes of average thickness respectively; (e) papillary or villous folds $-1+, 2+$, $3+=$ villi averaging up to $200,200-299$, and $500 \mu \mathrm{m}$ in length or more respectively; $(f)$ synovial giant cells $-1+, 2+, 3+=1-2,3-6$, and 6 or more cells/ medium power field $(\times 250)$ respectively; $(g) \frac{\mathrm{g}}{\mathrm{s}}$ Russells's bodies $-1+, 2+, 3+=1-2,3-6$, and 6 or more/medium power field $(\times 250)$ respectively; $(h) \underset{\text { 空 }}{2}$ fibrin exudation $-1+=$ minimal, $2+=$ moderate, 0 $3+=$ massive; $(i)$ plasma cells embedded in fibrous응 tissue $-1+, 2+, 3+=1-5,6-10$, and 10 or more cells/high power field respectively.

Numerical values were assigned to the histological findings according to these criteria, and the cases were divided into three groups based on their. histological scores (Table 1).

\section{Results}

The numerical values assigned to the inflammatory of response and the cathepsin $\mathrm{D}$ and acid phosphatase $\rightarrow$ activities in the synovial specimens obtained from 19 N osteoarthritic patients and 10 controls are given in 6 Tables 2 and 3 respectively.

Both cathepsin D and acid phosphatase activity were markedly increased in the osteoarthritic synovial tissue as compared with control synovium, and this increase was statistically significant (Tables $4 \vec{\oplus}$ and 5).

In the synovial tissues from the 19 osteoarthritic patients there was minimal inflammatory response in six cases (group I), medium in 10 (group II), and advanced in three (group III). No statistically significant correlation existed between the degree of

Table 2 Histological scores and lysosomal enzyme activities in osteoarthritic patients

\begin{tabular}{|c|c|c|c|c|c|c|c|c|c|c|c|c|}
\hline \multirow{2}{*}{$\begin{array}{l}\text { Patient } \\
\text { No and group }\end{array}$} & \multicolumn{9}{|c|}{ Histological criteria } & \multirow[t]{2}{*}{ Score } & \multicolumn{2}{|c|}{ Lysosomal enzyme activities } \\
\hline & $a$ & $b$ & $c$ & $d$ & $e$ & $f$ & $g$ & $h$ & $i$ & & Cathepsin D & $\begin{array}{l}\text { Acid } \\
\text { phosphatase }\end{array}$ \\
\hline \multicolumn{13}{|l|}{ Group I } \\
\hline 1 & 0 & + & 0 & + & + & 0 & 0 & 0 & 0 & 3 & 0.853 & 0.418 \\
\hline 2 & + & + & 0 & + & 0 & 0 & 0 & 0 & 0 & 3 & $1 \cdot 068$ & 0.477 \\
\hline 3 & 0 & + & 0 & + & + & 0 & 0 & 0 & 0 & 3 & $1 \cdot 404$ & $1 \cdot 557$ \\
\hline 4 & 0 & + & 0 & + & + & + & 0 & 0 & 0 & 4 & $1 \cdot 373$ & $1 \cdot 243$ \\
\hline 5 & 0 & + & 0 & + & + & 0 & 0 & ++ & 0 & 5 & 1.403 & $1 \cdot 146$ \\
\hline 6 & 0 & + & 0 & + & ++ & 0 & 0 & + & 0 & 5 & 0.537 & 0.436 \\
\hline \multicolumn{13}{|l|}{ Group II } \\
\hline 7 & 0 & + & 0 & + & ++ & 0 & 0 & + & + & 6 & $1 \cdot 419$ & $1 \cdot 150$ \\
\hline 8 & + & + & 0 & + & + & + & 0 & 0 & + & 6 & 0.413 & $0 \cdot 584$ \\
\hline 9 & 0 & + & + & + & +++ & 0 & 0 & + & 0 & 7 & $1 \cdot 015$ & 1.025 \\
\hline 10 & 0 & + & + & + & ++ & 0 & 0 & + & + & 7 & 1.694 & 1.074 \\
\hline 11 & + & + & + & + & + & + & 0 & + & 0 & 7 & 1.081 & $1 \cdot 849$ \\
\hline 12 & 0 & $+t$ & + & + & ++ & 0 & 0 & + & + & 8 & 2.929 & 1.900 \\
\hline 13 & 0 & ++ & 0 & + & +++ & + & 0 & 0 & + & 8 & 3.944 & $2 \cdot 844$ \\
\hline 14 & 0 & + & 0 & + & +++ & ++ & 0 & + & + & 9 & $1 \cdot 219$ & $0 \cdot 814$ \\
\hline 15 & 0 & + & 0 & ++ & ++ & + & 0 & ++ & + & 9 & $1 \cdot 569$ & $1 \cdot 390$ \\
\hline 16 & ++ & +++ & + & + & ++ & 0 & 0 & 0 & + & 10 & $2 \cdot 752$ & 1.921 \\
\hline \multicolumn{13}{|l|}{ Group III } \\
\hline 17 & + & ++ & + & + & +++ & ++ & 0 & + & + & 12 & $1 \cdot 070$ & 1.069 \\
\hline 18 & 0 & ++ & + & +++ & ++ & ++ & 0 & + & + & 12 & $2 \cdot 583$ & $1 \cdot 558$ \\
\hline 19 & 0 & +++ & 0 & + & ++ & ++ & 0 & +++ & + & 12 & $3 \cdot 049$ & 1.042 \\
\hline
\end{tabular}


Table 3 Lysosomal enzyme activities in the control group

\begin{tabular}{|c|c|c|c|}
\hline $\begin{array}{l}\text { Control } \\
\text { No }\end{array}$ & $\begin{array}{l}\text { Source of } \\
\text { material }\end{array}$ & $\begin{array}{l}\text { Cathepsin D } \\
\text { enzyme activities } \\
\text { (mg tyrosine/g synovial tissue) }\end{array}$ & $\begin{array}{l}\text { Acid phosphatase } \\
\text { enzyme activities } \\
\text { (mg phosphatelg wet weight synovial tissue) }\end{array}$ \\
\hline 1 & $\begin{array}{l}\text { Femoral neck fracture, } \\
\text { right knee }\end{array}$ & 0.558 & 0.453 \\
\hline 2 & $\begin{array}{l}\text { Amputation material, } \\
\text { left knee }\end{array}$ & 0.537 & 0.436 \\
\hline 3 & $\begin{array}{l}\text { Amputation material. } \\
\text { right knee }\end{array}$ & 0.520 & $0 \cdot 344$ \\
\hline 4 & $\begin{array}{l}\text { Arthrotomy material, } \\
\text { left knee }\end{array}$ & 0.527 & 0.407 \\
\hline 5 & $\begin{array}{l}\text { Amputation material, } \\
\text { left knee }\end{array}$ & 0.548 & 0.431 \\
\hline 6 & $\begin{array}{l}\text { Amputation material, } \\
\text { left knee }\end{array}$ & 0.517 & 0.389 \\
\hline 7 & $\begin{array}{c}\text { Amputation material, } \\
\text { left knee }\end{array}$ & $0 \cdot 602$ & 0.462 \\
\hline 8 & $\begin{array}{l}\text { Arthrotomy material, } \\
\text { right knee }\end{array}$ & $0 \cdot 648$ & 0.483 \\
\hline 9 & $\begin{array}{l}\text { Femoral neck fracture, } \\
\text { left hip }\end{array}$ & 0.563 & 0.420 \\
\hline 10 & $\begin{array}{l}\text { Arthrotomy material. } \\
\text { left knee }\end{array}$ & 0.546 & 0.392 \\
\hline
\end{tabular}

synovial tissue inflammation shown in each group and the corresponding lysosomal enzyme activities (Table 6).

\section{Discussion}

The role of the synovial membrane in the pathogenesis of osteoarthritis is not clear. Various studies $^{7915}$ concerning the synovial membrane and its lysosomal enzymes have produced conflicting results. This study was undertaken to try and resolve the controversy by using quantitative methods for determining the enzyme levels that had not previously been applied to synovium. In previous studies $^{7} 915$ homogenisation was used for the extraction of synovial enzymes. However, when we analysed five specimens by the homogenisation method for synovial tissue the enzyme levels measured varied considerably and were one fifth to one tenth of those obtained by the quantitative tissue section method used in this project. We believe that the homogenisation methods for cartilage and synovium are not accurate for the following reasons ${ }^{11}$ : (a) Homogenisation of tissue is difficult since particulate residue is always present and may contain significant amounts of enzyme activity. Thermal denaturation of enzymes is also a problem encountered in homogenisation. $(b)$ During homogenisation and separation of particulate debris there may be loss of the cofactors necessary for the hydrolysis of substrates, and an homogenate or extract with insufficient enzymatic activity may result. (c) Enzymatic activity determination with
Table 4 Comparison of cathepsin $D$ activities (mg tyrosine/g synovial tissue) in the osteoarthritic group with those in the control group

\begin{tabular}{|c|c|c|c|c|c|}
\hline Groups & Number & Mean & $\begin{array}{l}\text { Standard } \\
\text { deviation }\end{array}$ & $t$ & $p$ \\
\hline Control & 10 & 0.556 & $0 \cdot 040$ & & \\
\hline Osteoarthritis & 19 & $1 \cdot 651$ & 0.948 & $0 \cdot 046$ & 0.001 \\
\hline
\end{tabular}

Table 5 Comparison of acid phosphatase activities (mg phosphatelg wet weight synovial tissue) in the osteoarthritic group with those in the control group

\begin{tabular}{llllll}
\hline Groups & Number & Mean & $\begin{array}{l}\text { Standard } \\
\text { deviation }\end{array}$ & $t$ & $p$ \\
\hline Control & 10 & 0.421 & 0.040 & 5.905 & 0.001 \\
Osteoarthritis & 19 & 1.236 & 0.612 & & \\
\hline
\end{tabular}

Table 6 Correlation between the degree of synovial tissue inflammation and the lysosomal enzyme activity

\begin{tabular}{lll}
\hline Groups & Mann-Whitney $U$ values & $p$ \\
\hline I-II $(n=6)$ & 46 & $0 \cdot 05$ \\
I-III $(n=10)$ & 16 & $0 \cdot 05$ \\
II-III $(n=3)$ & 26 & $0 \cdot 05$ \\
\hline
\end{tabular}

such homogenates results in lower enzymatic activity values per gram of tissue as compared with our method of estimation.

In the method ${ }^{2}{ }^{11} 13$ employed in this study 
weighed tissue $(0.3 \mathrm{~g})$ was diced and sectioned (18 $\mu \mathrm{m})$ and incubated directly with the substrate in a buffered solution. Thus the hydrolysis of the substrates in the solution could be measured quantitatively under optimum conditions, yielding higher enzyme activity levels. For this reason we believe that our method is more reliable and accurate than those previously used.

The mean cathepsin $\mathrm{D}$ activity in the 19 osteoarthritic synovial tissue specimens was found to be $1.651 \mathrm{mg}$ tyrosine/g synovial tissue (Table 4 ). In the 10 normal synovial tissue specimens comprising the control group it was $0.556 \mathrm{mg}$ tyrosine/g synovial tissue. The significantly increased cathepsin D activity in the osteoarthritic specimens confirms the findings of $\mathrm{Kar}^{9}$ and Salvati, ${ }^{7}$ even though these investigators used homogenisation methods.

In our work there was also a statistically significant increase in the acid phosphatase levels in osteoarthritic synovial tissue and this is in accordance with the findings of Kar. ${ }^{9}$ However, Waxman $^{15}$ and Salvati ${ }^{7}$ did not detect significantly increased levels of this enzyme in their studies. Their inability to detect higher activity levels of this enzyme may be due to loss of enzyme activity in the methods they used. Since acid phosphatase is a marker for lysosomal activity in tissues the findings of Waxman ${ }^{15}$ and Salvati ${ }^{7}$ that cathepsin D levels were increased in the presence of normal acid phosphatase levels appear somewhat contradictory, but it is possible for the level of one lysosomal enzyme to be raised and not that of the other.

In osteoarthritis conflicting findings have been reported for the relationship between lysosomal enzyme levels and the developing synovitis. ${ }^{79}$ In our study a statistically significant relationship between the degree of inflammation in the synovial membrane and the activity levels of both enzymes could not be found (Table 6). Even though the number of cases analysed are few, Kar's ${ }^{9}$ results confirm this finding. For example in Kar's ${ }^{9}$ eight cases cathepsin D activity did not correlate with histological degrees of synovial inflammation. Salvati, 7 however, did find a correlation between the degree of inflammation in the osteoarthritic synovial tissue and cathepsin D activity. As mentioned above the differences between our findings and those of Salvati $^{7}$ may be explained by the different techniques employed to detect enzyme activities. It should be mentioned that the poor diagnostic value of synovial biopsy in patients with arthritis is well known and that there is usually a better correlation as regards the findings in synovial fluid. ${ }^{16}$ Recent morphological observations by Shiozawa et al. ${ }^{14}$ indicate that even in rheumatoid arthritis the cartilage destruction is mediated by fibroblasts and fibroblast derived macrophages at the cartilage-pannus junction. Thus in osteoarthritises too it appears that the synovium derived cells ando macrophages may also contribute to the destruction of the cartilage by producing increased amounts of $\frac{\bar{n}}{\overline{7}}$ lysosomal degradative enzymes, extracellular pro- $₫$ teases, or even catabolin-like factors which wouldw facilitate cartilage breakdown. ${ }^{5}$

Based on our findings we conclude that: $(a)$ in $\vec{\circ}$ osteoarthritis cathepsin $\mathrm{D}$ activity is significantly $\vec{\omega}$ increased in the synovial tissues; $(b)$ acid phosphatase activity is also increased, and since this enzyme is a marker for lysosomal enzyme activity this may indicate a general increase in degradativer enzymes; (c) no correlation exists between lyso somal enzyme activity and the degree of inflamma tion in the osteoarthritic synovium.

\section{References}

1 Ali S Y. New knowledge of osteoarthrosis. J Clin Pathol 1978음 12 (suppl 31): 191-9.

2 Ali S Y, Bayliss M T. Enzymic changes in human osteoarthrotie cartilage. In: Ali S Y, Elves M W, Leaback D H, eds. Normapo and osteoarthrotic articular cartilage. London: Institute of Orthopaedics, 1974: 189-203.

3 Howell D S, Sapolsky A I, Pita J C, Woessner J F. The pathogenesis of osteoarthritis. Semin Arthritis Rheum 1976;4은 365-83.

4 Chrisman O D. Fessel J M, Southwick W O. Experimentā production of synovitis and marginal articular exostoses in the knee of dogs. Yale J Biol Med 1965; 37: 409-12.

5 Fell H B. Synoviocytes. J Clin Pathol 1978; 12 (suppl 31) 14-24.

6 Gedikoglu O. Osteoartrit patogenezinde synovyal membra疋 lizozomal enzimlerinin rolu. In: Ege R, ed. VII. Milli Turk̂ Ortopedi ve Travmatoloji Kongre Kitabi, Ankara 1983: 254-7

7 Salvati E A, Granda J L, Mirra J, Wilson P D. Clinical enzymatic and histologic study of synovium in coxarthrosis. $\ln \frac{}{\mathrm{n}}$ Orthop 1977; 1: 39-42.

8 Glynn L E. Primary lesion in osteoarthritis. Lancet 1977; 574-5.

9 Kar N C, Cracchiolo A, Mirra J, Pearson C M. Acid, neutra and alkaline hydrolases in arthritic synovium. Am J Clin Pathob 1976; 65: 220-8.

10 Radin E L. Aetiology of osteoarthritis. Clin Rheum Dis 1976: 27 509-22.

11 Ali S Y, Evans L, Stainthorpe E, Lack C H. Characterization of cathepsins in cartilage. Biochem $J$ 1967; 105: 549-57.

12 Evans L, Sayers D C J, Ali S Y. A method of preparation of

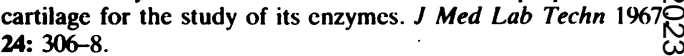

13 Bayliss M T, Ali S Y. Studies on cathepsin B in human articulao cartilage. Biochem J 1978; 171 : 149-54.

14 Shiozawa S, Shiozawa K, Fujita T. Morphologic observations if the early phase of cartilage-pannus junction. Light and electrof microscopic studies of active cellular pannus. Arthritis Rheun ${ }^{+}$ 1983; 26: 472-8.

15 Waxman B A, Sledge B C. Correlation of histochemical histologic and biochemical evaluations of human synovium wit clinical activity. Arthritis Rheum 1973; 16: 376-82.

16 Gibson $T$, Fagg N, Highton J, Wilton M, Dyson M. ThE diagnostic value of synovial biopsy in patients with arthritis of unknown cause. Br J Rheumatol 1985; 24: 232-41. 